\title{
Ground-Water Movement and Water Quality in Lake Point, Tooele County, Utah, 1999-2003
}

\section{Scientific Investigations Report 2006-5124}

U.S. Department of the Interior

U.S. Geological Survey 
Cover photo: View from Great Salt Lake south to Lake Point area, Tooele County, Utah, 2006. 


\section{Ground-Water Movement and Water Quality in Lake Point, Tooele County, Utah, 1999-2003}

By T.A. Kenney, S.J. Wright, and B.J. Stolp

Scientific Investigations Report 2006-5124

Prepared in cooperation with

TOOELE COUNTY, UTAH DEPARTMENT OF NATURAL

RESOURCES, DIVISION OF WATER RIGHTS; AND

LAKE POINT IMPROVEMENT DISTRICT

U.S. Department of the Interior

U.S. Geological Survey 


\section{U.S. Department of the Interior \\ Dirk Kempthorne, Secretary}

\section{U.S. Geological Survey \\ P. Patrick Leahy, Acting Director}

Reston, Virginia: 2006

For additional information write to:

U.S. Geological Survey

Director, USGS Utah Water Science Center

2329 W. Orton Circle

Salt Lake City, UT 84119-2047

Email: GS-W-UTpublic-info@usgs.gov

URL: http://ut.water.usgs.gov/

For more information about the USGS and its products:

Telephone: 1-888-ASK-USGS

World Wide Web: http://www.usgs.gov/

Any use of trade, firm, or product names is for descriptive purposes only and does not imply endorsement by the U.S. Government

Although this report is in the public domain, permission must be secured from the individual copyright owners to reproduce any copyrighted materials contained within this report. 


\section{Contents}

Abstract

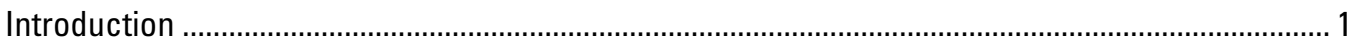

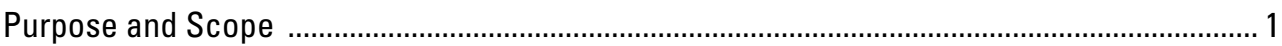

Numbering System for Hydrologic-Data Sites in Utah .......................................................... 1

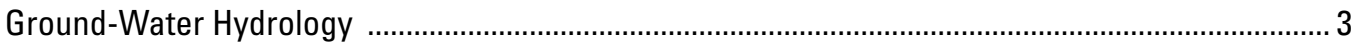

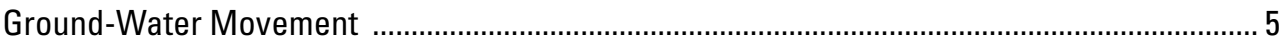

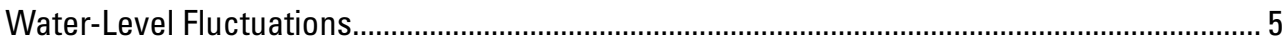

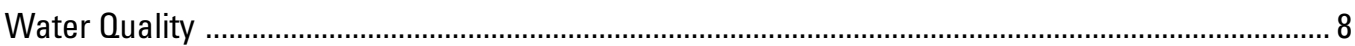

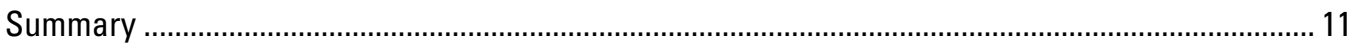

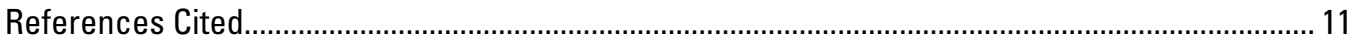

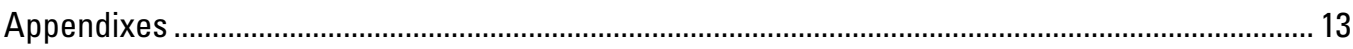

\section{Figures}

Figure 1. Location of Lake Point study area, Tooele County, Utah. ..................................................... 2

Figure 2. Numbering system for hydrologic-data sites in Utah. ....................................................... 3

Figure 3. Potentiometric surface developed from water levels measured in wells, Lake Point, Tooele County, Utah, April 2002 ................................................................................................. 4

Figure 4. Dissolved-solids concentration of water samples collected from wells completed in the basin fill, Lake Point, Tooele County, Utah. ………............................................................. 6

Figure 5. Water-level fluctuation in selected wells completed in the basin fill, Lake Point, Tooele County, Utah. 7

Figure 6. Major-ion composition of water samples collected from wells in the Lake Point area, Tooele County, Utah, 2001.

Figure 7. Chemical composition and dissolved-solids concentration of water samples collected from wells in the Lake Point area, Tooele County, Utah, 2001.

Figure 8. Mixing line constructed between freshwater and Great Salt Lake water in relation to weight ratio of bromide to chloride in water samples, Lake Point, Tooele County, Utah, 2001.

Figure 9. Specific conductance of water samples collected during drilling of the triplecompletion well at (C-2-4)10bda (map ID 42), Lake Point, Tooele County, Utah, 2002.

\section{Table}

Table 1. Density-corrected water levels for two multiple-completion wells, Lake Point, Tooele County, Utah 


\section{Conversion Factors, Datums, and Abbreviated Water- Quality Units}

\begin{tabular}{|c|c|c|}
\hline Multiply & By & To obtain \\
\hline acre & 0.4047 & hectare (ha) \\
\hline foot $(\mathrm{ft})$ & 0.3048 & meter $(\mathrm{m})$ \\
\hline mile (mi) & 1.609 & kilometer $(\mathrm{km})$ \\
\hline square mile $\left(\mathrm{mi}^{2}\right)$ & 2.590 & square kilometer $\left(\mathrm{km}^{2}\right)$ \\
\hline
\end{tabular}

Horizontal coordinate information is referenced to the North American Datum of 1983 (NAD 83).

Vertical coordinate information is referenced to the North American Vertical Datum of 1929 (NAVD 29).

Altitude, as used in this report, refers to distance above the vertical datum.

Chemical concentration is reported only in metric units. Chemical concentration is reported in milligrams per liter $(\mathrm{mg} / \mathrm{L})$ or micrograms per liter $(\mu \mathrm{g} / \mathrm{L})$. Milligrams per liter is a unit expression the solute per unit volume (liter) of water. One thousand micrograms per liter is equivalent to 1 milligram per liter. For concentrations less than 7,000 milligrams per liter, the numerical value is about the same as for concentrations in parts per million. Specific conductance is represented in microsiemens per centimeter at 25 degrees Celsius $(\mu \mathrm{S} / \mathrm{cm})$ 


\title{
Ground-Water Movement and Water Quality in Lake Point, Tooele County, Utah, 1999-2003
}

\author{
By T.A. Kenney, S.J. Wright, and B.J. Stolp
}

\section{Abstract}

Water-level and water-quality data in Lake Point, Tooele County, Utah, were collected during August 1999 through August 2003. Water levels in Lake Point generally declined about 1 to 2 feet from July 2001 to July 2003, likely because of less-than-average precipitation. Ground water generally flows in two directions from the Oquirrh Mountains. One component flows north toward the regional topographic low, Great Salt Lake. The other component generally flows southwest toward a substantial spring complex, Factory/Dunne's Pond. This southwest component flows through a coarse gravel deposit believed to be a shoreline feature of historic Lake Bonneville. The dominant water-quality trend in Lake Point is an increase in dissolved-solids concentration with proximity to Great Salt Lake. The water type changes from calcium-bicarbonate adjacent to the Oquirrh Mountains to sodium-chloride with proximity to Great Salt Lake. Evaluation of chloride-bromide weight ratios indicates a mixture of fresher recharge waters with a brine similar to what currently exists in Great Salt Lake.

\section{Introduction}

Lake Point is a small, rural community of about 1,000 residents located in the northeastern corner of Tooele County in Utah (fig. 1). Lake Point, as used in this report, also refers to the approximately $6-\mathrm{mi}^{2}$ ground-water basin delineated on the north by Great Salt Lake, on the east by the topographic divide of the Oquirrh Mountains, and on the south by a bedrock extension from the Oquirrh Mountains. Lake Point is experiencing growth and potential large-scale residential development as a bedroom community of Salt Lake City, Utah. Ground water is the source of drinking water for the area and a clear understanding of the hydrologic system is critical for protection of both the amount and quality of ground water.

The U.S. Geological Survey (USGS), in cooperation with Tooele County; Utah Department of Natural Resources, Division of Water Rights; and Lake Point Improvement District investigated of the ground-water hydrology of Lake Point to provide knowledge for management of the area's groundwater resources. The objectives of the investigation were to determine (1) ground-water flow directions, (2) the pattern and magnitude of water-level fluctuations, (3) water-quality conditions in the consolidated-rock and basin-fill aquifers, (4) the effects of ground-water withdrawals on water levels, (5) the effects of ground-water withdrawals on ground-water flow direction, and (6) the effects of ground-water withdrawals on water quality.

\section{Purpose and Scope}

This report presents water-quality and water-level data collected in Lake Point during August 1999 through August 2003. The data presented define a baseline for the climatic conditions and hydrologic stresses that existed in Lake Point during 2001-03. Subjects presented and discussed in this report include (1) ground-water flow direction, (2) the pattern and magnitude of water-level fluctuations, and (3) water-quality conditions.

\section{Numbering System for Hydrologic-Data Sites in Utah}

The system of numbering wells, springs, and other hydrologic-data sites in Utah is based on the cadastral land-survey system of the U.S. Government. The number, in addition to designating the site, describes its position in the land net. The land-survey system divides the State of Utah into four quadrants by the Salt Lake Base Line and the Salt Lake Meridian. These quadrants are designated by the uppercase letters A, B, $\mathrm{C}$, and $\mathrm{D}$, which indicate, respectively, the northeast, northwest, southwest, and southeast quadrants. Numbers that designate the township and range (in that order) follow the quadrant letter, and all three are enclosed in parentheses. The number after the parentheses indicates the section and is followed by three lowercase letters that indicate the quarter section, the quarter-quarter section, and the quarter-quarter-quarter section - generally 10 acres for regular sections . The lowercase letters a, b, c, and d indicate, respectively, the northeast, northwest, southwest, and southeast quarters of each subdivision. The number after the letters is the serial number of the well or spring within the 10 -acre plot. The letter $\mathrm{S}$ preceding the serial number denotes a spring. Thus, (C-2-4)2dda-1 designates the first well constructed or visited in the NE 1/4 of the SE 1/4, of the SE 1/4, Sec. 2, T.2 S., R.4 W. The capital letter C indicates that the township is south of the Salt Lake Base Line and

\footnotetext{
${ }^{1}$ Although the basic land unit, the section, is theoretically $1 \mathrm{mi}^{2}$, many sections are irregular. Such sections are subdivided into 10-acre tracts, generally beginning at the southeast corner, and the surplus or shortage is taken up in the tracts along the north and west sides of the section.
} 


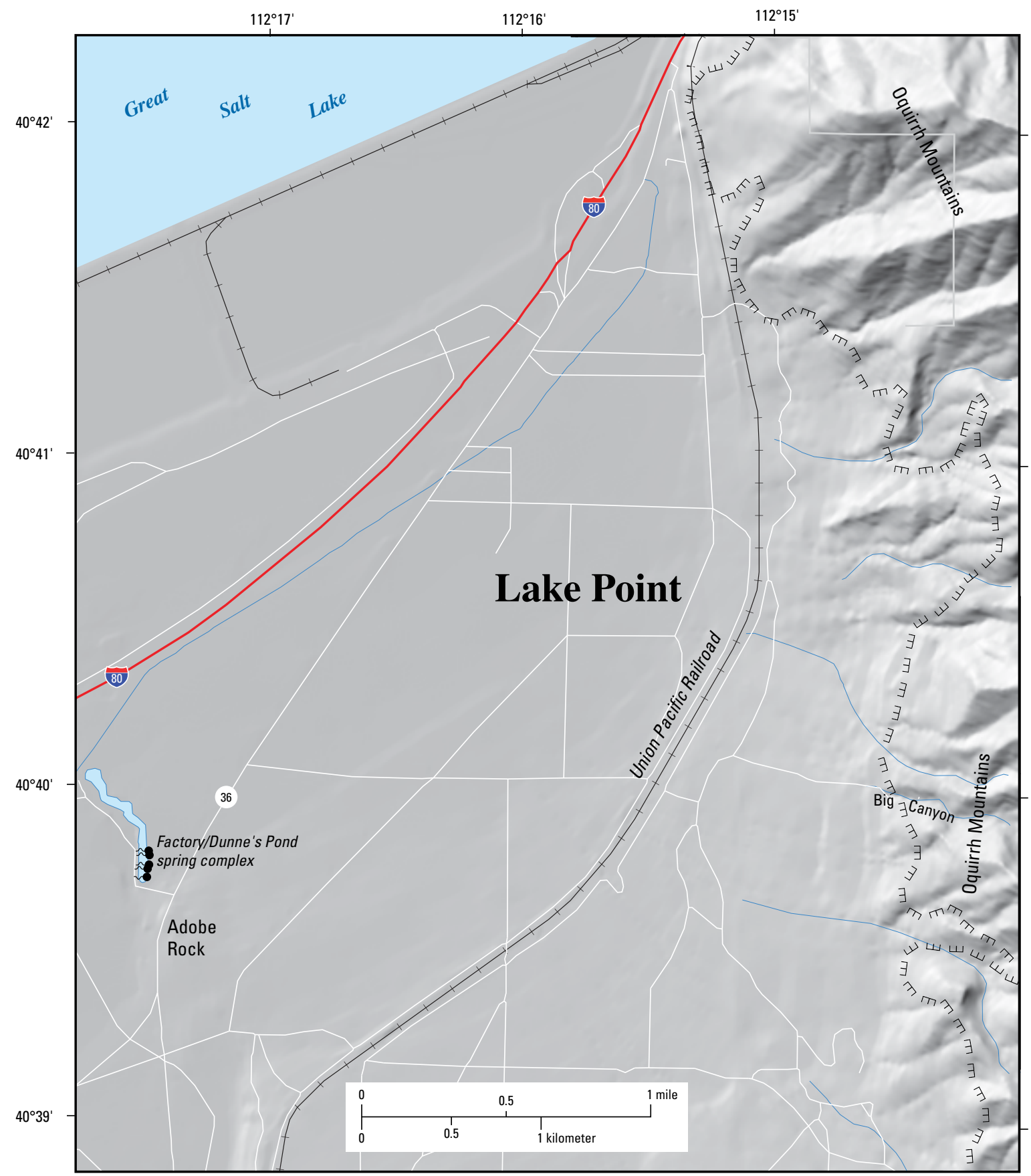

Base from U.S. Geological Survey digital line graph data, $1972,1: 24,000$

Universal Transverse Mercator projection, Zone 12

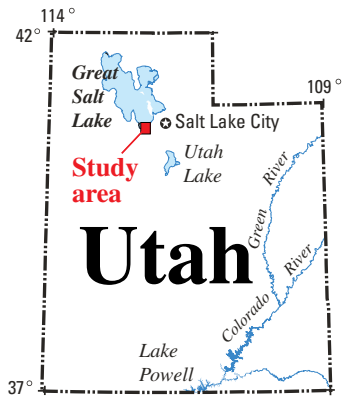

\section{EXPLANATION}

ш Approximate boundary of basin fill

- Spring

Figure 1. Location of Lake Point study area, Tooele County, Utah. 
Sections within a township

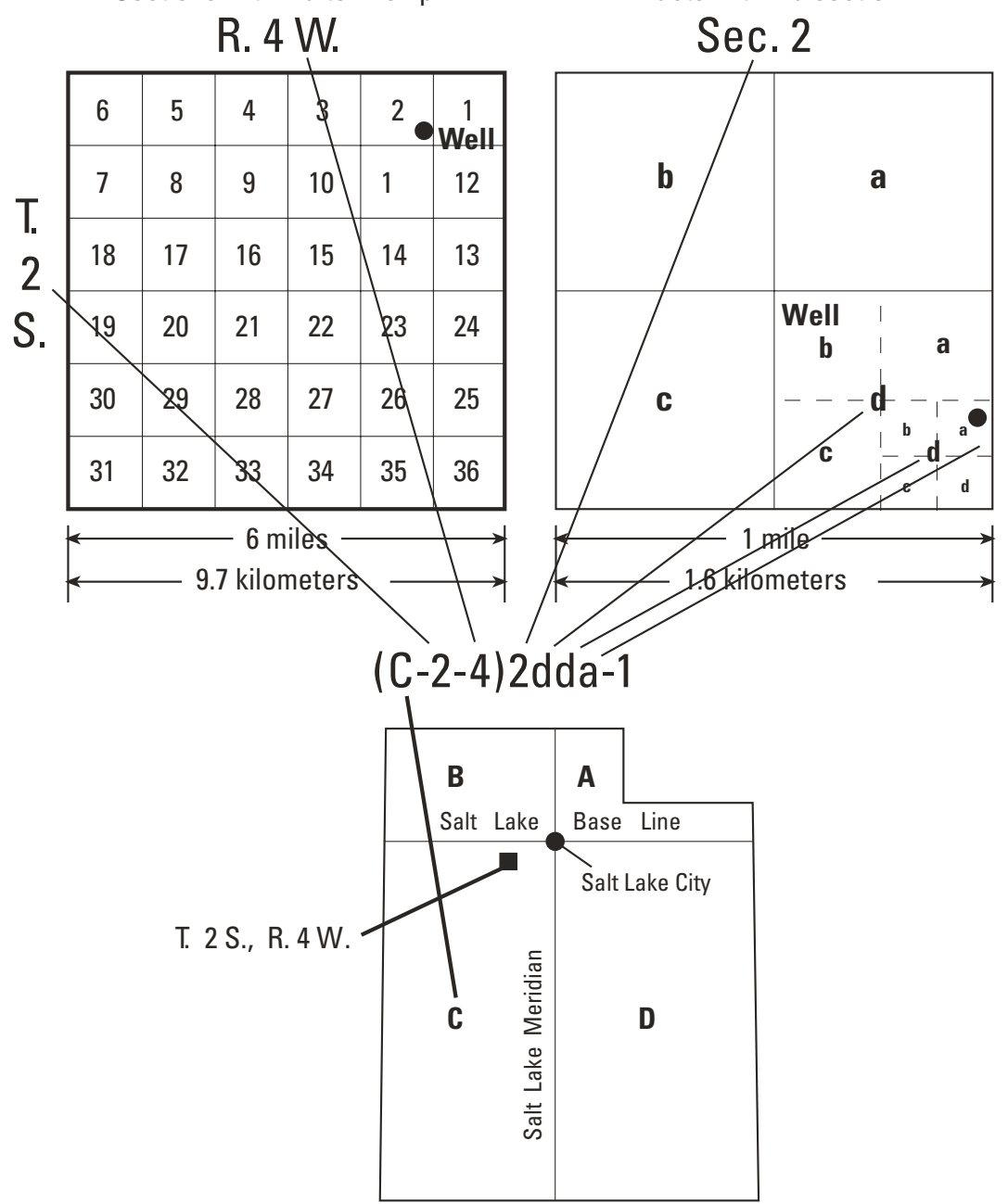

Figure 2. Numbering system for hydrologic-data sites in Utah.

the range is west of the Salt Lake Meridian. The numbering system is shown in figure 2 .

\section{Ground-Water Hydrology}

Ground water in Lake Point occurs in consolidated rock and basin fill. The consolidated rock is primarily quartzite and limestone; ground-water flow is mainly through fracture zones in the quartzite. The basin fill consists mostly of alluvial and lacustrine deposits that originated from the Oquirrh Mountains. Ground water in the basin fill exists under both watertable and confined conditions. Much of the basin-fill lithology was controlled by lake-level fluctuations of prehistoric Lake Bonneville, which existed from about 25,000 to 10,000 years ago (Currey, 1980). Lake fluctuations created a variety of depositional environments that ranged from beaches to water as deep as 1,000 ft. Alluvial deposits along the eastern and southern margins of the Lake Point area (fig. 3) were subjected to considerable wave action during several stages of
Lake Bonneville. This wave action removed the fine-grained sediment from the alluvium, leaving behind relatively clean, coarse-grained gravel deposits, which are highly conductive for ground-water flow. Deep-water deposits, consisting mainly of silts and clays, have created confined conditions and lower permeability in the central and western areas of Lake Point.

Ground water is recharged mainly by infiltration to consolidated rock of the Oquirrh Mountains from melting snow and rainfall. The water moves through the subsurface to the adjacent basin fill. Some recharge occurs directly to the basin fill as ephemeral streamflow runoff from the Oquirrh Mountains, and as infiltration of precipitation and unconsumed irrigation water. Ground water is discharged (1) from the basin fill to Factory/Dunne's Pond spring complex (fig. 3), (2) by dispersed seepage to salt flats and marshy areas bordering Great Salt Lake, (3) by subsurface inflow to Great Salt Lake, (4) to flowing wells, and (5) by evapotranspiration. 


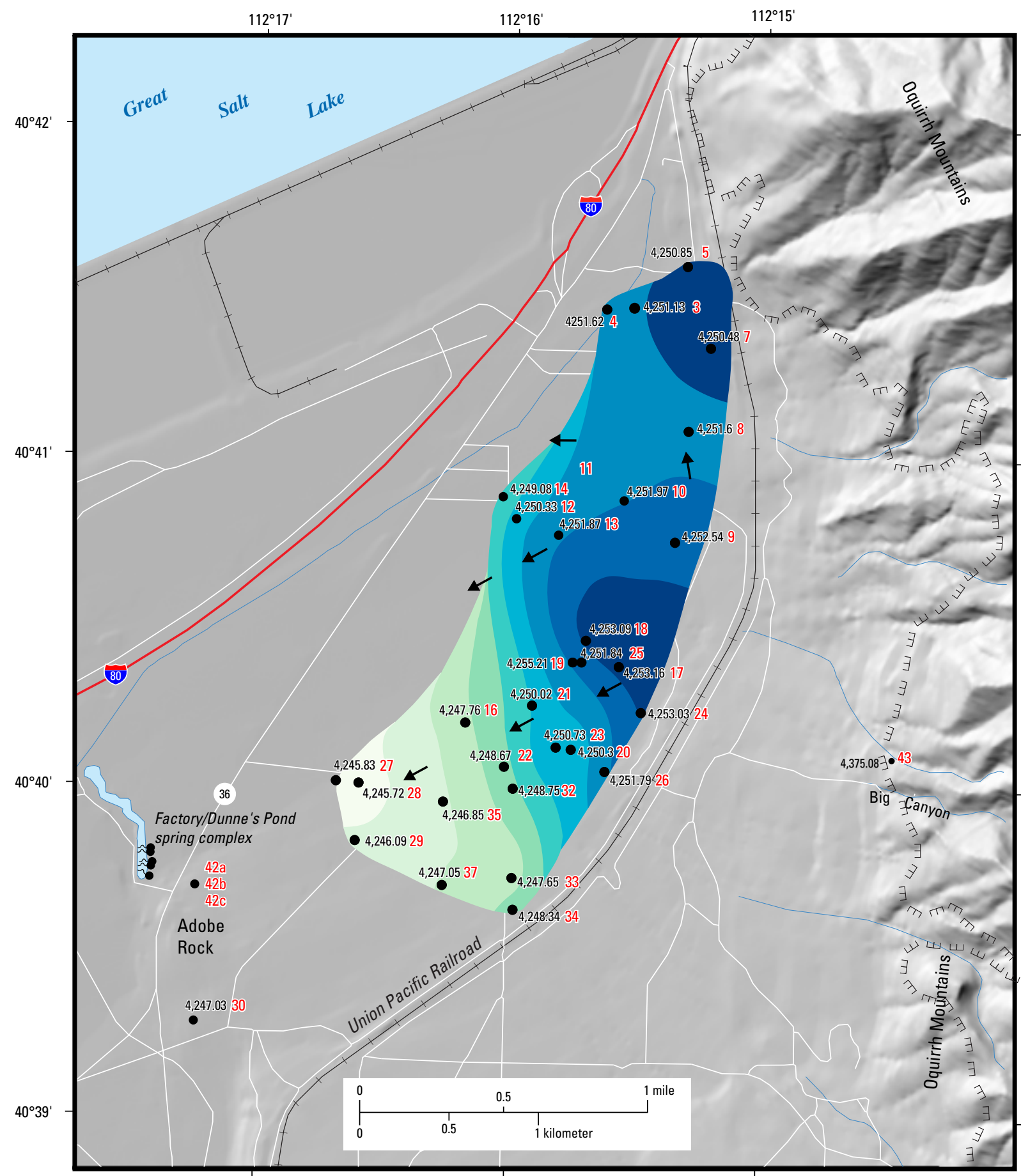

Base from U.S. Geological Survey digital line graph data, $1972,1: 24,000$

Universal Transverse Mercator projection, Zone 12

EXPLANATION
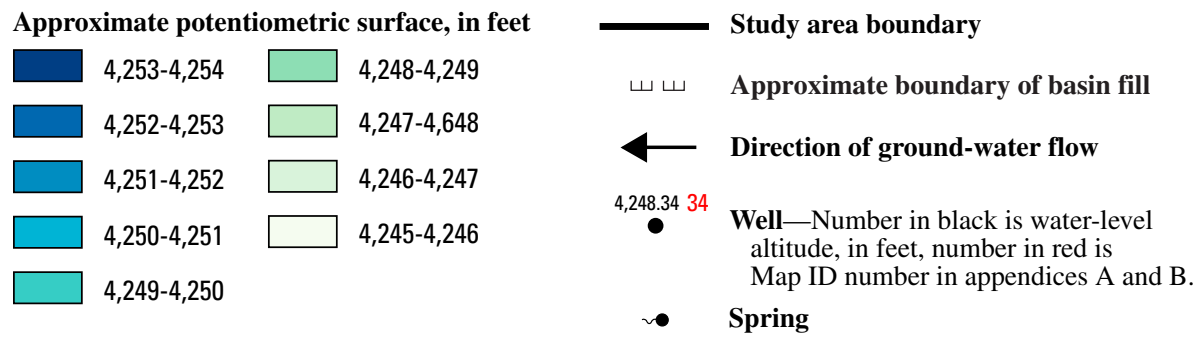

Figure 3. Potentiometric surface developed from water levels measured in wells, Lake Point, Tooele County, Utah, April 2002. 


\section{Ground-Water Movement}

To determine the direction of ground-water movement, water levels were measured at 31 wells on April 9 and 10, 2002 (appendix 1 ). A potentiometric water surface was delineated by using 29 of the 31 measured water levels. Each well was surveyed from established benchmarks, which allowed measured water levels to be converted to ground-water altitudes. Ground-water altitudes ranged from about 4,253 ft near the eastern foothills to about 4,246 ft near Factory/Dunne's Pond spring complex. Measured water levels at wells (C-24)2dba-1 and (C-2-4)2ddb-1 (map IDs 19 and 25 on fig. 3) were not used to map the potentiometric water surface. In comparison with other water-level measurements at the wells the values are not considered erroneous, but rather inconsistent with the local trend. They are inconsistent both in difference and in absolute altitude. The wells are located about $150 \mathrm{ft}$ apart and the difference in water levels is about $3.5 \mathrm{ft}$. Total water-level difference across the study area (about $2 \mathrm{mi}$ ) is about $9 \mathrm{ft}$. The water level at the eastern well (map ID 25) is lower than the local trend; the water level at the western well (map ID 19) is higher than the local trend. Reasons for the irregularities are unknown but might be associated with physical characteristics of the wells or local water use.

Wells used for monitoring water levels are completed in the basin fill and range in depth from 40 to $451 \mathrm{ft}$, with most being less than $200 \mathrm{ft}$. The potentiometric surface (fig. 3) was not adjusted for effects from vertical hydraulic gradients. The arrows delineate the general direction of ground-water flow. The highest ground-water altitudes occur in the alluvium adjacent to the Oquirrh Mountains, indicating ground-water inflow to the basin fill. From these areas, ground water generally flows in two directions. One component moves north toward Great Salt Lake, the regional topographic low. The second component generally flows to the southwest through a coarse-grained gravel deposit believed to be a shoreline feature of prehistoric Lake Bonneville along the southern boundary of Lake Point, toward Factory/Dunne's Pond spring complex.

Although vertical gradients were not evaluated spatially, data are available to examine vertical water-level differences at two triple-completion monitoring wells (fig. 4, map IDs 8 and 42). At both well sets the density of water, as measured by dissolved-solids concentration (table 1), increases with depth. Because of this, measured water levels were corrected to compensate for density differences (table 1). At the triple-completion well located at the base of the Oquirrh Mountains (fig. 4, map ID 8, well (C-1-4)36ccb) the vertical gradient indicates that ground-water is moving from the underlying consolidated rock to the adjacent basin fill. This is in agreement with the concept of recharge as subsurface flow from the consolidated mountain block. At the triple-completion well located just east of the Factory/Dunne's Pond spring complex (fig. 4, map ID 42, well (C-2-4)10bda) the vertical gradient is upward, agreeing with the concept and observations (the spring complex) that ground water is discharging in this area.

\section{Water-Level Fluctuations}

Water-level fluctuations in the Lake Point area were evaluated on the basis of continuously recorded water levels at 3 wells (fig. 5) (Herbert and others, 1999, 2000, 2001; Wilberg and others, 2002; and Tibbetts 2003) and 2 years of monthly water-level measurements collected at 21 wells (appendix 1 ). Thirteen of the 21 wells measured monthly are used for domestic culinary water, and the remaining 8 wells were not in use during the study. Beginning in 1958 well (C-2-4)2baa-3 has been measured annually by the USGS (Burden and others, 2003, p. 34). Water levels for nine wells measured during this study are shown in figure 5 .

Table 1. Density-corrected water levels for two multiple-completion wells, Lake Point, Tooele County, Utah

[Screened interval: Depth to the center of the screened interval as measured from land surface. Density: Determined from dissolved-solids concentration by using the following equation: density $=($ dissolved-solids concentration $/ 1,590,000)+1$ (Lines, 1978). Density-corrected water levels: Corrected to be equivalent to the water level if the water had a dissolved-solids concentration of 0.0 milligrams per liter; density-corrected water level $=\left[\left(\rho / \rho_{\mathrm{f}}\right) \mathrm{h}\right]+\mathrm{Z}_{\mathrm{n}}$; where $\rho$ is density of water, $\rho_{\mathrm{f}}$ is density of fresh water, $h$ is height of water column in well above screened interval, $Z_{n}$ is elevation of the screened interval. Completion: The material that the screens are located in. Upward vertical gradient exists when the water level at a deeper screened interval is higher than the water level at a shallower screened interval]

\begin{tabular}{|c|c|c|c|c|c|c|c|c|}
\hline $\begin{array}{l}\text { Map } \\
\text { ID }\end{array}$ & $\begin{array}{c}\text { Screened } \\
\text { interval, in } \\
\text { feet }\end{array}$ & $\begin{array}{c}\text { Water-level } \\
\text { altitude, in } \\
\text { feet }\end{array}$ & $\begin{array}{c}\text { Date of } \\
\text { water level }\end{array}$ & $\begin{array}{l}\text { Dissolved- } \\
\text { solids } \\
\text { concentration, } \\
\text { in milligrams } \\
\text { per liter }\end{array}$ & $\begin{array}{l}\text { Date of } \\
\text { water } \\
\text { sample }\end{array}$ & Density & $\begin{array}{l}\text { Density- } \\
\text { corrected } \\
\text { water-level } \\
\text { altitude, } \\
\text { in feet }\end{array}$ & Completion \\
\hline $8 \mathrm{a}$ & $4,116.50$ & $4,250.80$ & $6 / 18 / 2003$ & 1,000 & $6 / 18 / 2003$ & 1.00063 & $4,250.86$ & basin fill \\
\hline $8 b$ & $3,996.00$ & $4,251.54$ & $6 / 18 / 2003$ & 1,190 & $6 / 18 / 2003$ & 1.00074 & $4,251.73$ & basin fill \\
\hline $8 \mathrm{c}$ & $3,793.00$ & $4,250.78$ & $6 / 18 / 2003$ & 5,790 & $6 / 18 / 2003$ & 1.00364 & $4,252.30$ & consolidated rock \\
\hline $42 \mathrm{a}$ & $4,120.00$ & $4,230.92$ & $7 / 18 / 2003$ & 1,240 & $8 / 9 / 2002$ & 1.00078 & $4,230.96$ & consolidated rock \\
\hline $42 b$ & $4,020.00$ & $4,230.90$ & $7 / 18 / 2003$ & 6,810 & $8 / 9 / 2002$ & 1.00428 & $4,231.59$ & consolidated rock \\
\hline $42 \mathrm{c}$ & $3,980.00$ & $4,230.95$ & $7 / 18 / 2003$ & 22,400 & $8 / 9 / 2002$ & 1.01409 & $4,234.56$ & consolidated rock \\
\hline
\end{tabular}




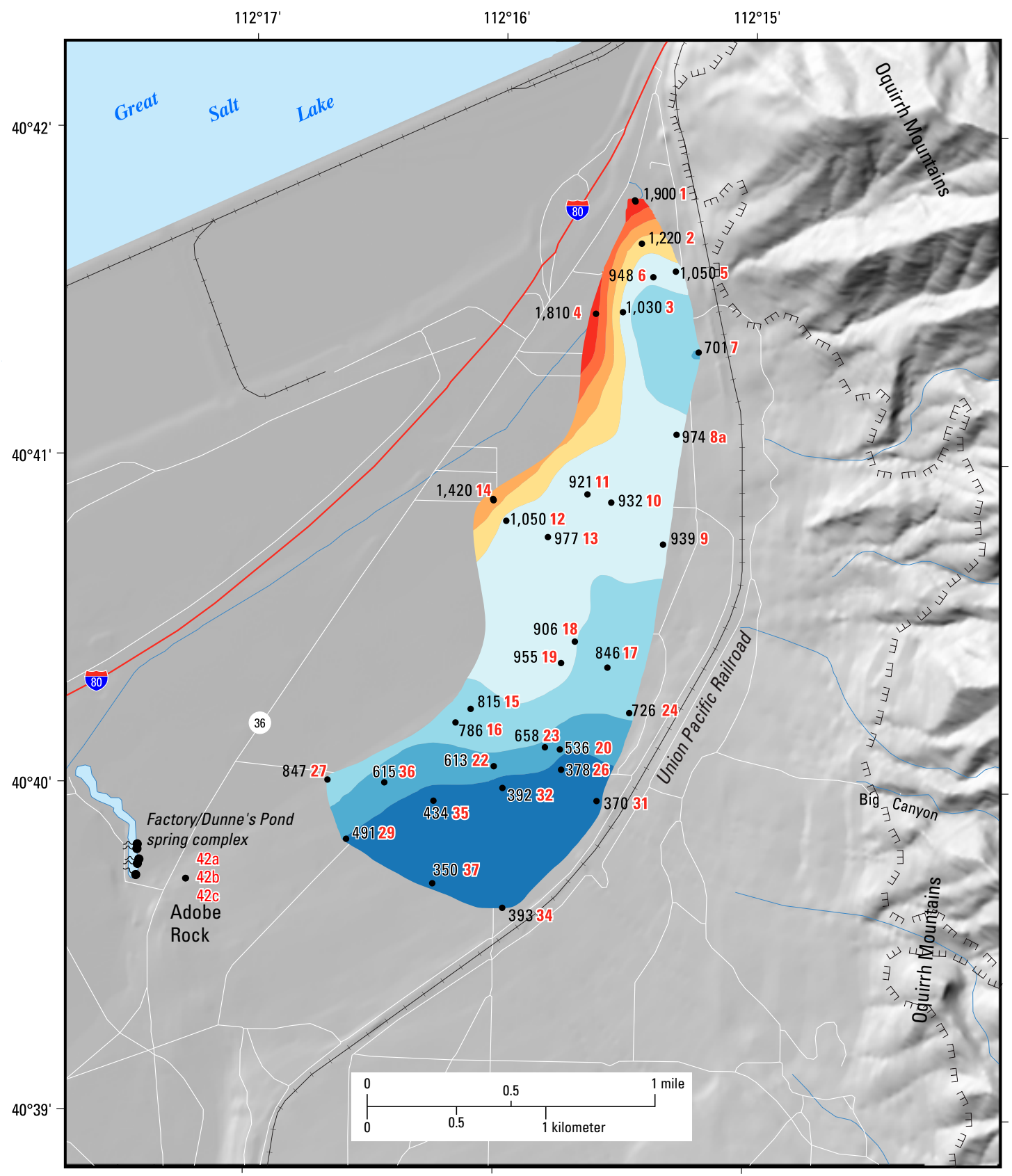

Base from U.S. Geological Survey digital line graph data, $1972,1: 24,000$

Universal Transverse Mercator projection, Zone 12

\section{EXPLANATION}

Dissolved-solids concentration, in milligrams per liter

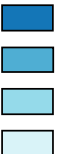

300 to 500

500 to 700

700 to 900

900 to 1,100 $\sqcup \sqcup$ Approximate boundary of basin fill

• 39334 Well-Number in black is dissolved-solids concentration, in milligrams per liter

Number in red is map ID number in appendices A and B

- Spring

Figure 4. Dissolved-solids concentration of water samples collected from wells completed in the basin fill, Lake Point, Tooele County, Utah. 

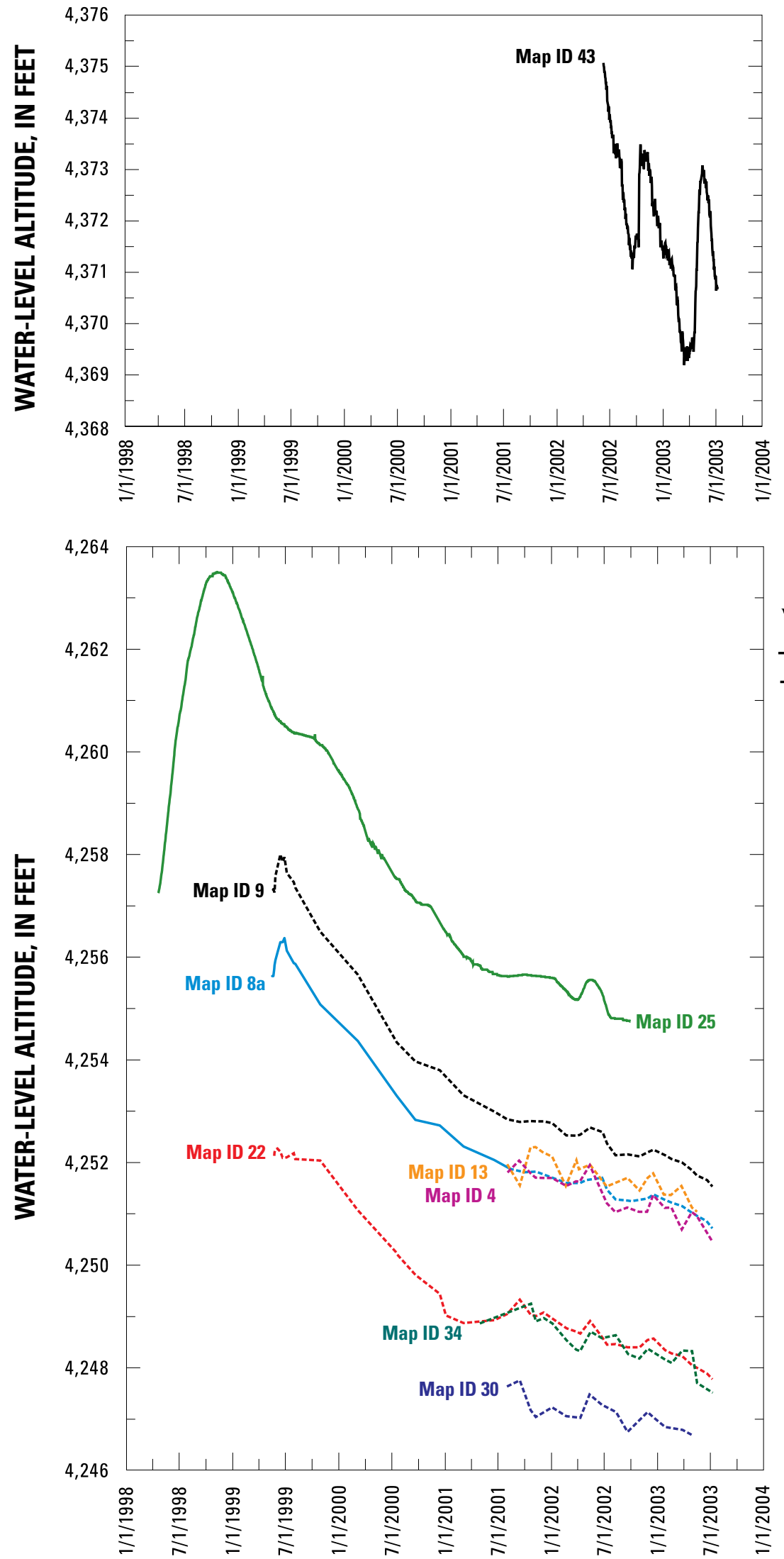

EXPLANATION

Water-level measurements

Continuous Monthly

Previously published continuous water-levels for well(C-2-4)2ddb-1 (map ID 25) beginning April 1998 are shown.

Figure 5. Water-level fluctuation in selected wells completed in the basin fill, Lake Point, Tooele County, Utah. 
In general, water-level fluctuations are monitored to gain understanding of ground-water recharge/discharge processes. When recharge exceeds discharge, water levels rise. Conversely, when discharge is greater than recharge, water levels decline. Discharge created by withdrawals from wells will affect water levels.

Water levels in the Lake Point area generally declined from 1999 through 2003, likely because of less-than-average precipitation. A decline of about $9 \mathrm{ft}$ was recorded at well (C2-4)2ddb-1(map ID 25) (fig. 5) from November 1998 to September 2002. Precipitation for the same time period in Tooele Valley (as measured at climate stations in Tooele City and Grantsville, Utah) was about 85 percent of the long-term average (Western Regional Climate Center, 2003). The 9-ft decline may be exaggerated because it follows a period of elevated water levels, the result of 5 years (1993-98) of greater-thanaverage precipitation (Burden and others, 2003, p. 32). Waterlevel declines for July 2001 to July 2003 ranged from about 1 to $2 \mathrm{ft}$. This decline is probably more in keeping with the magnitude of decline that can be expected with precipitation at 85 percent of the long-term average.

Seasonal water-level rises and declines are on the order of $0.5 \mathrm{ft}$ and show neither a strong nor a consistent pattern. This would indicate that recharge and discharge rates in the Lake Point area do not vary much during the year. At well (C-24)1ddc-1, located at the mountain front (map ID 43) (fig. 5) and completed in consolidated rock, water-level fluctuations are larger and more frequent. This is likely caused by a lower storage capacity for consolidated rock and the proximity of the well to mountain recharge areas.

\section{Water Quality}

To make an assessment of ground-water quality in the Lake Point area, water from 32 wells was sampled in June or December 2001 following the guidelines outlined in the National Field Manual for the Collection of Water-Quality Data (U.S. Geological Survey, variously dated). Twentyfour of the 32 wells supply water to homes for domestic use; 8 wells were not in use. Four of the 8 wells not in use are observation wells drilled by the USGS that have been sampled annually since 1999. Water-quality data are listed in appendix 2. Field measurements of specific conductance, $\mathrm{pH}$, water temperature, and dissolved oxygen were taken with a multiparameter water-quality meter. Dissolved iron was measured in the field with a Chemetrics Photometer. Analyses for common ions, nutrients, and metals were done by the USGS National Water Quality Laboratory. Dissolved-solids concentrations were determined as both the residue on evaporation at 180 degrees Celsius and computed as the sum of individually determined components.

The spatial distribution of water quality in the Lake Point area is shown in figure 4. The dominant trend is an increase in dissolved solids with proximity to Great Salt Lake. Ground water farthest from Great Salt Lake in the sampled wells had a dissolved-solid concentration that ranges from about 350 to $550 \mathrm{mg} / \mathrm{L}$. Dissolved-solids concentration in water from wells closer to the lake increases to about 2,000 mg/L. These changes in water quality are illustrated in Stiff and tri-linear diagrams, which show the proportions of individual chemical species dissolved in water. Stiff diagrams (fig. 6) show positively charged ions (cations) on the left of the center line and negatively charged ions (anions) to the right. The distance that a vertex is from the center line is proportional to the concentration of the chemical species; overall size of the Stiff diagram is related to dissolved solids. Each Stiff diagram in figure 6 represents a single water sample and is identified using the map IDs shown in figure 4. Waters in southernmost Lake Point have a fairly even distribution of components with a slight dominance of calcium and bicarbonate. Water samples collected in areas north and west trend toward increasing sodium/potassium and chloride. Although sodium and potassium are aggregated on the Stiff diagrams, examination of analytical results in appendix 2 indicates that the increases are a result almost exclusively of chloride. On the tri-linear diagram shown in figure 7, water samples are plotted three times, once in each of the lower triangles and once in the center field. Triangle plots show composition as a percentage of total cations and anions. Data points in the central field are intersections of points in the lower triangles. Individual water samples shown in figure 7 are identified according to dissolved-solids concentration and use the same color scheme used in figure 4 . The tri-linear diagram illustrates the correlation between dissolved solids and principal ions and shows that increases in dissolved solids are caused by sodium and chloride.

The most likely reason for increases in dissolved-solids concentration at Lake Point is mixing with water containing higher concentrations of dissolved solids. As shown in figure 4, water quality at Lake Point degrades toward Great Salt Lake, which in 2003 had an average dissolved-solids concentration of about 150,000 mg/L. More specifically, water degrades because of increases in sodium and chloride, the predominant ions present in Great Salt Lake water. The trend toward increased dissolved-solids concentration with proximity to Great Salt Lake persists even in areas of Lake Point where ground-water movement is perpendicular to the lake (southern area in figs. 3 and 4). If dissolved-solids concentrations were increasing as a result of contact time and dissolution of minerals contained within the aquifer, dissolved-solids concentrations would increase along the general direction of ground-water movement. Data collected during this study are insufficient to establish either a hydrologic connection to Great Salt Lake, or that the gradation of water quality is a result of residual pore water.

Increases in dissolved solids from about $350 \mathrm{mg} / \mathrm{L}$ to $2,000 \mathrm{mg} / \mathrm{L}$ are significant in terms of drinkable water, but minor when considering mixing with poor-quality waters that have characteristics similar to those of water contained within Great Salt Lake. A theoretical mixing of 1 percent Great Salt Lake water (with dissolved-solids concentration of 

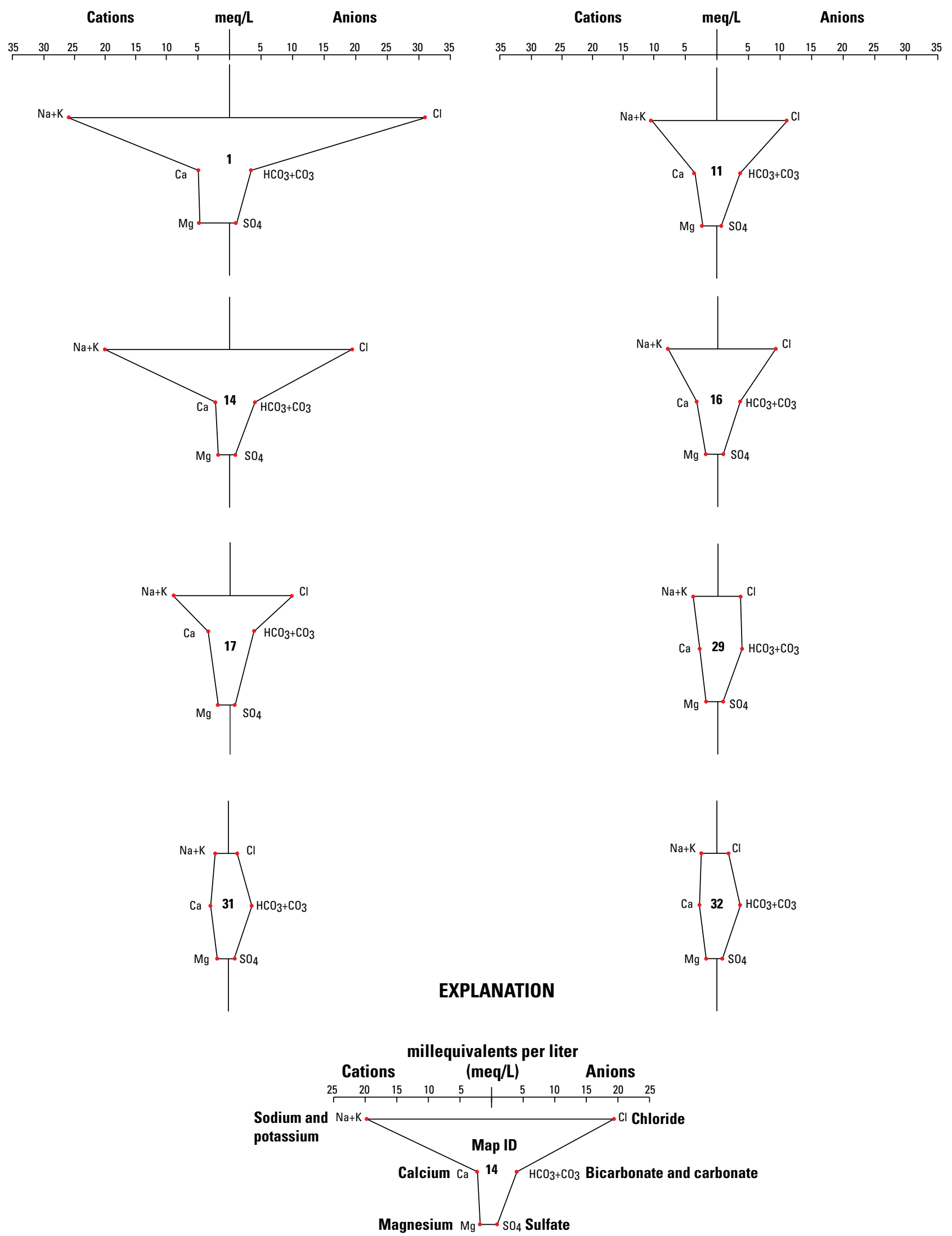

Figure 6. Major-ion composition of water samples collected from wells in the Lake Point area, Tooele County, Utah, 2001. 


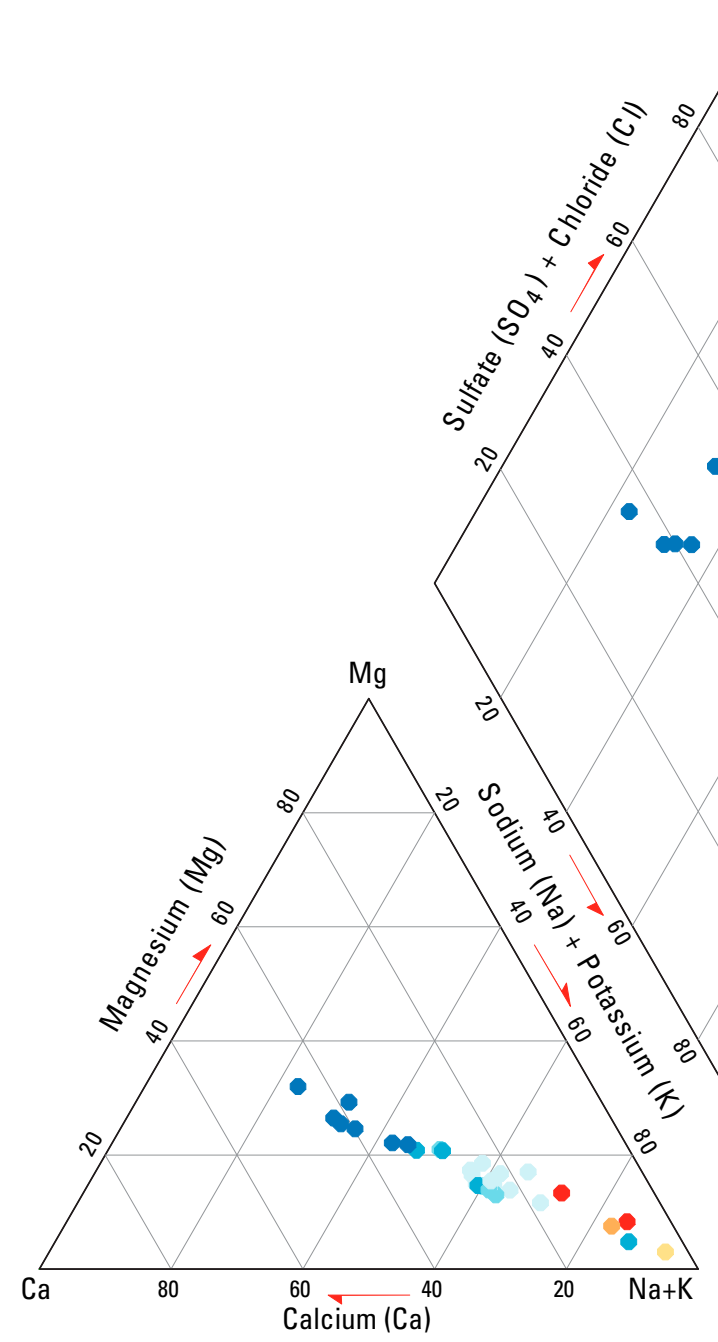

CATIONS

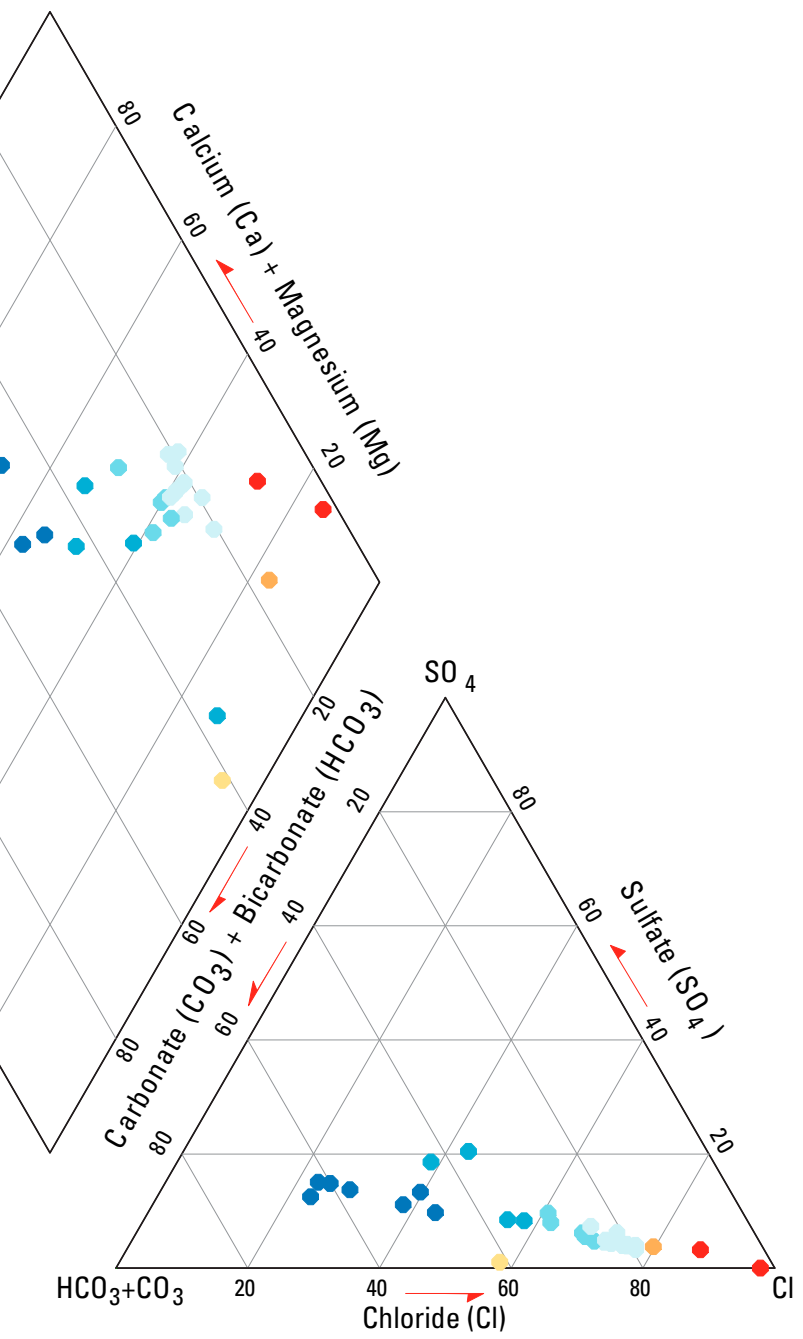

A N I O N S

\section{PERCENT OF TOTAL MILLIEOUIVALENTS PER LITER}

\section{EXPLANATION}

Dissolved-solids concentration, in milligrams per liter
- 300 to 500
1,100 to 1,300
- 500 to 700
1,300 to 1,500
700 to 900
- 1,500 to 1,700
900 to 1,100
- 1,700 to 1,900

Figure 7. Chemical composition and dissolved-solids concentration of water samples collected from wells in the Lake Point area, Tooele County, Utah, 2001. 
$150,000 \mathrm{mg} / \mathrm{L}$ ) mixed with the freshest water in Lake Point $(352 \mathrm{mg} / \mathrm{L})$ can create the range of dissolved-solids concentrations detected in Lake Point. The ratio of bromide to chloride concentrations with increasing salinity indicates that this mixing is occurring (fig. 8). Both bromide and chloride are (1) conservative ions that do not participate in complex geochemical reactions, (2) uncommon in most rock-forming minerals, and (3) highly soluble in evaporite minerals. This means that ground water that has not mixed with waters from other sources nor dissolved evaporite minerals will retain a bromide/ chloride ratio similar to that of the precipitation from which it is derived, and the trend with increasing salinity would be horizontal. Bromide-to-chloride ratios in waters at Lake Point indicate a relative increase or enrichment of chloride with respect to bromide. A mixing line constructed from the previously described blend of Great Salt Lake and Lake Point waters shows a theoretical trend that is almost identical to the observed trend. The average concentration of bromide and chloride in Great Salt Lake was determined from 69 samples of water collected in November, 2002 (Blair Jones, U.S. Geological Survey, written commun., 2003).

At the two triple-completion monitoring wells that exist in the study area, (fig. 4, map IDs 8a-c and 42a-c, wells (C-14)36ccb and (C-2-4)10bda), water quality degrades with depth. Samples collected during the drilling of wells (C-2-4)10dba$1,2,3$ show that specific-conductance values increased from about 2,000 $\mu \mathrm{S} / \mathrm{cm}$ at a depth of $250 \mathrm{ft}$ to almost 35,000 $\mu \mathrm{S} /$ $\mathrm{cm}$ at a depth of $300 \mathrm{ft}$ (fig. 9). Water samples collected from wells (C-1-4)36ccb-1,2,3 also show a change in water quality with depth. Dissolved-solids concentrations vary from about $1,000 \mathrm{mg} / \mathrm{L}$ in the shallow completion, a depth of 104 feet, to $5,790 \mathrm{mg} / \mathrm{L}$ in the deep completion, a depth of 477 feet.

During sampling, three quality-assurance samples were collected. One replicate sample was collected at well (C-14)26ddd-1 (map ID 1), and two field blank samples were collected at wells (C-2-4)2baa-3 and (C-2-4)2dca-1 (map IDs 14 and 20). A replicate is a second sample of water, presumed to be identical to an initial sample, collected immediately after the initial sample, at a given site. Replicates indicate the level of variation within the sampling and laboratory analysis process. A field blank is a sample of ultra-purified water that is subjected to identical collection and processing as a normal water sample. Blanks check field processing, preservation, transportation, and laboratory handling. Field blanks quantify whether and to what degree water samples may have been contaminated. The presence of solutes in the field blank indicates that some part of the field or laboratory process is adding constituents (contaminating) the original water sample.

On the basis of field blank data, there is no indication of sample contamination during field and laboratory processing. No constituent was measured at concentration above the minimum detection limit of the analytical method. The replicate sample indicates that for all constituents except arsenic and manganese, values were within 5 percent of the initial sample. For arsenic and manganese, values were within 10 percent. Five-percent differences are reasonable given the inherent vari- ability of field processes and laboratory analyzes. Differences in the 5-to-10 percent range indicate variability that could possibly have been avoided with more uniform adherence to prescribed field procedures. Only tentative interpretations of replicate comparisons can be made on the basis of one replicate sample. Differences should be considered as a general measure of confidence interval. Reported values in appendix 2 are likely within 5 percent of the true value; for arsenic and manganese, reported values are likely within 10 percent.

\section{Summary}

This report presents water-level and water-quality data collected in Lake Point by the USGS in cooperation with Tooele County; Utah Department of Natural Resources, Division of Water Rights; and Lake Point Improvement District during August 1999 through August 2003. Ground water in Lake Point occurs in consolidated rock and basin fill. Much of the basin-fill lithology was controlled by lake-level fluctuations of prehistoric Lake Bonneville. Ground-water recharge is mainly by infiltration to consolidated rock of the Oquirrh Mountains, and ground water moves in the subsurface to the basin fill. Ground water discharges to springs, salt flats, Great Salt Lake, flowing wells, and evapotranspiration. Ground water generally flows in two directions from the Oquirrh Mountains. One component flows north toward Great Salt Lake, and the second component flows southwest toward Factory/Dunne's Pond spring complex.

Water levels in Lake Point generally declined about 1 to $2 \mathrm{ft}$ from July 2001 to July 2003, likely because of less-thanaverage precipitation. Seasonal fluctuations are on the order of $0.5 \mathrm{ft}$ and do not show a strong nor consistent pattern.

The dominant water-quality trend in Lake Point is an increase in dissolved-solids concentration with proximity to Great Salt Lake. The water type changes from calcium-bicarbonate adjacent to the Oquirrh Mountains to sodium-chloride with proximity to Great Salt Lake. Evaluation of bromide-tochloride weight ratios indicates a mixture of fresher recharge waters with a brine similar to what currently exists in Great Salt Lake.

\section{References Cited}

Burden, C.B., and others, 2003, Ground-water conditions in Utah, Spring of 2003, Utah Division of Water Resources Cooperative Investigations Report No. 44, 120 p.

Currey, D.R., 1980, Coastal geomorphology of Great Salt Lake and vicinity: Utah Geological and Mineral Survey Bulletin, v. 116, p. 69-92. 


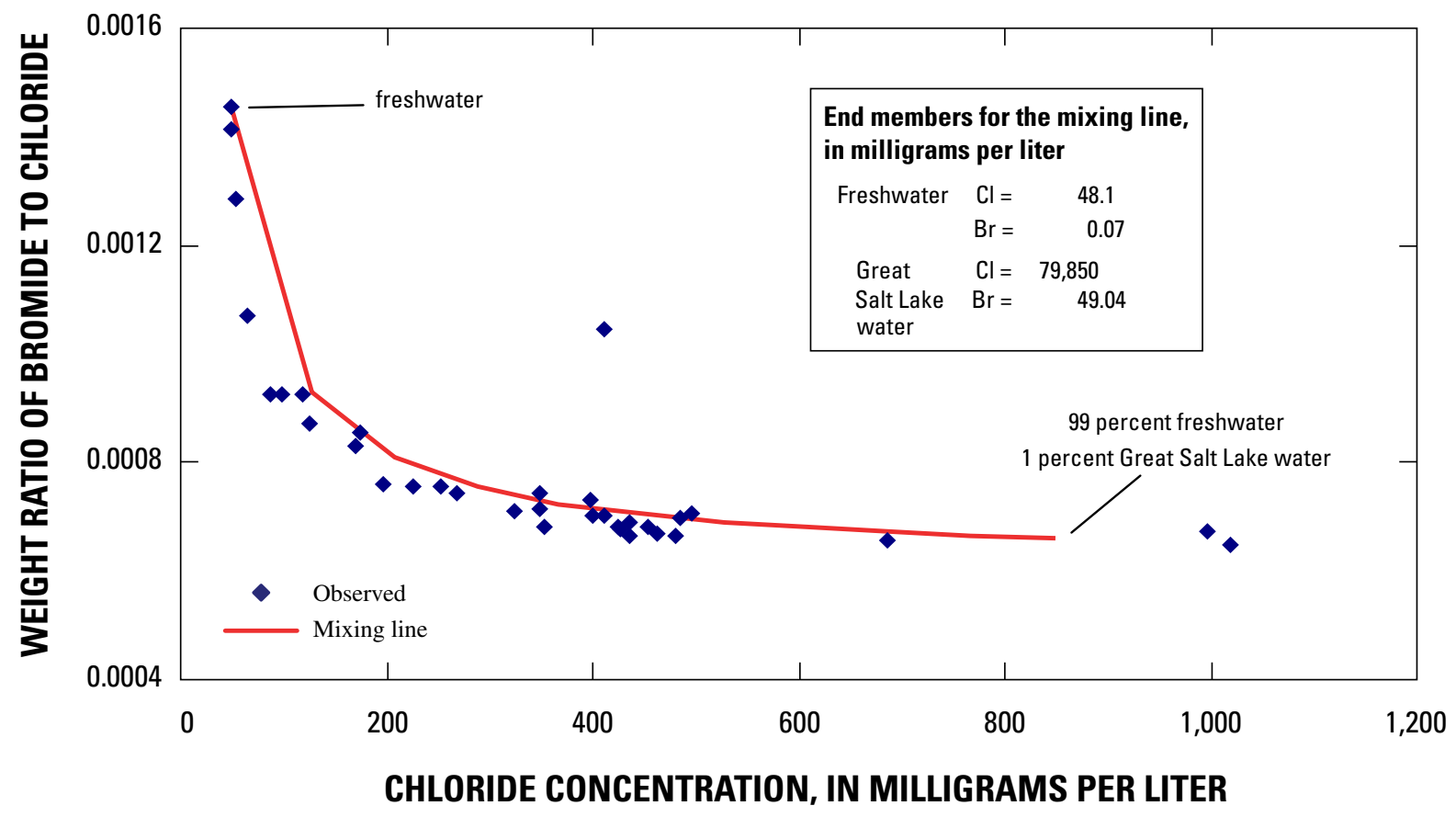

Figure 8. Mixing line constructed between freshwater and Great Salt Lake water in relation to weight ratio of bromide to chloride in water samples, Lake Point, Tooele County, Utah, 2001.

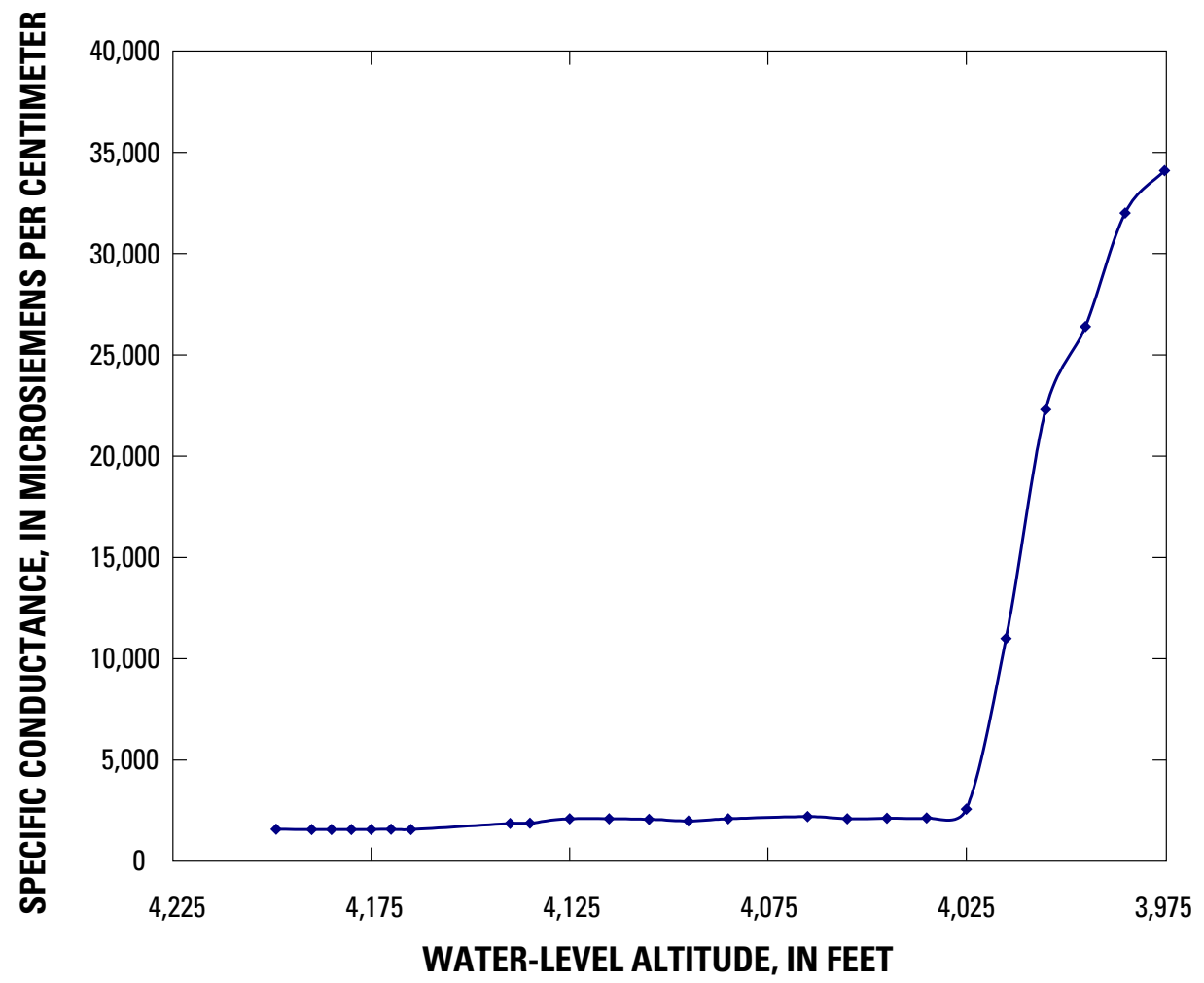

Figure 9. Specific conductance of water samples collected during drilling of the triple-completion well at (C-2-4)10bda (map ID 42), Lake Point, Tooele County, Utah, 2002. 
Herbert, L.R., Allen, D.E., Wilberg, D.V., and Tibbetts, J.R., 1999, Water resources data, Utah: U.S. Geological Survey Water-Data Report UT-99-1, 340 p.

Herbert, L.R., Wilberg, D.E., Tibbetts, J.R., and Allen, D.V., 2000, Water resources data, Utah: U.S. Geological Survey Water-Data Report UT-00-1, 380 p.

Herbert, L.R., Wilberg, D.V., and Tibbetts, J.R., 2001, Water resources data, Utah: U.S. Geological Survey Water-Data Report UT-01-1, 440 p.

Lines, G.C., 1978, Selected ground-water data, Bonneville Salt Flats and Pilot Valley, western Utah: U.S. Geological Survey Open-File Report (unnumbered and duplicated as Utah Basic-Data Report 30), 14 p.

Tibbetts, J.R., Enright, Michael, and Wilberg, D.E., 2003, Water resources data, Utah: U.S. Geological Survey WaterData Report UT-03-1, 458 p.

U.S. Geological Survey, variously dated, National field manual for the collection of water-quality data: U.S. Geological Survey Techniques of Water-Resources Investigations, book 9, chaps. A1-A9, available online at http://pubs.water.usgs. gov/twri9A

Western Regional Climate Center, 2003, Historical climate information, accessed November 25, 2003, at http://www. wrcc.dri.edu

Wilberg, D.E., Tibbetts, J.R., and Enright, Michael, 2002, Water resources data, Utah: U.S. Geological Survey WaterData Report UT-02-1, 391 p.

\section{Appendixes}

Appendixes may be accessed through the following links:

Appendix 1. Water level in selected wells in the Lake Point area, Tooele County, Utah, measured from August 1999 through August 2003. [Appendix 1.pdf]

Appendix 2. Physical characteristics and chemical quality of water from selected wells and springs, Lake Point, Tooele County, Utah. [Appendix2.pdf] 


\section{趈}

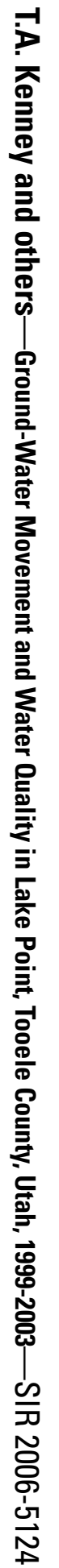

